\title{
Chemometric Analysis of Volatile Compounds of NIPRINEEM Oil and Other Brands of Neem Seed Oils Sold in Nigeria
}

\author{
0. P. Adigwe, J. A. Ibrahim, A. Adamu*, S. E. Okhale, A. Elias, H. O. Egharevba \\ Department of Medicinal Plant Research and Traditional Medicine, National Institute for Pharmaceutical Research and \\ Development, Abuja, Nigeria \\ Email: ^adamualiyu246@gmail.com
}

How to cite this paper: Adigwe, O.P., Ibrahim, J.A., Adamu, A., Okhale, S.E., Elias, A. and Egharevba, H.O. (2022) Chemometric Analysis of Volatile Compounds of NIPRINEEM Oil and Other Brands of Neem Seed Oils Sold in Nigeria. Journal of Biophysical Chemistry, 13, 1-12.

https://doi.org/10.4236/jbpc.2022.131001

Received: November 5, 2021

Accepted: February 21, 2022

Published: February 24, 2022

Copyright $\odot 2022$ by author(s) and Scientific Research Publishing Inc. This work is licensed under the Creative Commons Attribution International License (CC BY 4.0).

http://creativecommons.org/licenses/by/4.0/

\begin{abstract}
Azadirachta indica A. Juss (neem, family Meliaceae) is a reputable medicinal plant. Various parts of the plant are used as a remedy against different ailments, as a natural pesticide, as raw material in the cosmetic industry, and for marking other commodities. The seed oil is a major product of the plant and its quality depends on the seed quality and extraction methods employed. In this study, the chemical profile of NIPRDNEEM oil is compared with that of other brands of neem seed oils by using gas chromatography-mass spectrometry (GC-MS) and chemometrics. The fatty acid identified in NIPRDNEEM oil were: oleic acid (34.09\%), stearic acid (11.4\%), linoleic acid (15.94\%), palmitic acid (23.4\%), arachidic acid $(0.73 \%)$, and the other compounds were: 1-Monolinoleoylglycerol trimethylsilyl ether $(0.95 \%)$ and farnesyl alcohol (13.20\%). The branded oils were composed predominantly of oleic acid $(13.50 \%$ - 26.76\%), palmitic acid (6.88\% - 11.99\%), linoleic acid (7.32\% $11.17 \%)$, stearic acid $(4.29 \%-13.08 \%)$, and arachidic acid $(0.53 \%-1.27 \%)$. The unbranded oil contained oleic acid (30.04\%), stearic acid (14.91\%), linoleic acid (14.62\%), palmitic acid (12.34\%), and arachidic acid (0.93\%). Stigmasterol, stigmasterol acetate, and sitosterol were the sterols identified in the oils. Characterization of the fatty acid profile of neem seed oil is vital for industrial and economic purposes. The fatty acids profile of the NIPRDNEEM oil and other neem seed oil were comparable. Both PCA plots and HCA dendrogram from the chemometric analysis shows three main grouping of all samples. While NIPRDNEEM and the local neem oil were grouped, suggesting a high degree of resemblance of both samples.
\end{abstract}

\section{Keywords}

Azadirachta indica, NIPRDNEEM, Seed Oil, Fatty Acids, GCMS 


\section{Introduction}

Azadirachta indica A. Juss (neem) of the family of Meliaceae, is one of the most versatile medicinal plants with a wide range of applications in human health care and pest control. The different parts of neem (fruits, seeds, leaves, flowers, roots, hardwood, and bark) are used as traditional medicine against various human ailments. The plant also finds application as a natural pesticide, as a raw material for the cosmetic industry, and for making other commodities [1] [2] [3] [4]. The main neem product is the oil extracted from the seeds by different techniques. Neem seed oil possesses biological activity against some micro-organisms that cause infections in humans. It possesses anthelmintic, antileprotic (prevents leprosy), antibacterial, and anti-dermatophytes activities. Neem seed cake is an active ingredient in the preparation of mosquito repellent coil. Attention is increasingly being paid to the use of natural compounds to replace agrochemicals in agricultural pest control. The neem seed oil has been identified as a promising option for agricultural pest control. Neem oil contains at least 100 biologically active compounds. Among them, the major constituents are triterpenes known as limonoids, the most important being azadirachtin, which appears to cause $90 \%$ of antifeedant effects on most pests. Other components present include meliantriol, nimbin, nimbidin, gedunin, nimbinin, nimbolide, salannin and fatty acids (oleic, stearic, and palmitic). Nimbidin isolated from neem seeds is effective in reducing fasting blood glucose [5]. Among the botanical insecticides currently marketed, neem oil is one of the least toxic to humans and shows very low toxicity to beneficial organisms, so it is, therefore, being used for the control of many pests. Targets organisms include the following: Anopheles stephensi [6], A. culicifacies [7], Ceraeochrysa claveri [8] [9], Cnaphalocrocis medinalis [10], Diaphorina citri [11], Helicoverpa armigera [12], Mamestra brassicae [13], Nilaparvata lugens (Stål) [14], Pieris brassicae [15] and Spodoptera frugiperda [16].

Chemometric implies the application of mathematics and statistical tools to improve the understanding of chemical information and to correlate quality parameters, chemical properties, or physical properties to analytical instrument data. It is applied to solve descriptive and predictive problems in chemical analysis. Due to the nature of the factors that might contribute to consumer preference, multivariate chemometrics tools, especially pattern recognition techniques, are helpful tools for the characterization of products based on certain parameters. These parameters could include chemical, physical, and instrumental analysis [17]. In this study, the characterization of the neem oil is based on unsupervised pattern recognition techniques such as principal component analysis (PCA), and hierarchical cluster analysis (HCA). Despite the wide usage of chemometrics in data analysis in other countries of the world, it is an emerging aspect of quality control chemistry in Nigeria. This study intends to apply chemometric analysis to investigate and compare the differences in the chemical composition of NIPRDNEEM and other brands of neem oil.

The quality of neem seed oil is usually dependent on the seed quality and the 
extraction methods employed [18]. Mechanical pressing, solvent extraction, and more recently, supercritical fluid extraction (SFE), are among the numerous methods used to extract neem seed oil [19]. To ensure steady availability of high-grade neem oil, The National Institute for Pharmaceutical Research and Development, NIPRD, a Federal Government parastatal under the Federal Ministry of Health, Nigeria, has the mandate of the Honourable Minister of Health to produce high-grade neem seed oil called NIPRDNEEM oil. This study was designed to compare the chemical profile of branded, unbranded, local, and foreign neem seed oils with NIPRDNEEM. This study is important because the high demand for neem oil could result in cases of adulteration and sales of substandard neem oil. In this study, the fatty acid profile and presence of other volatile compounds will be used for quality control assessment of NIPRDNEEM oil to ensure consistency in our neem oil production.

\section{Material and Methods}

\subsection{Sampling and Sample Preparation and Extraction}

The neem oils used in this study were categorised as branded and unbranded. The branded samples were neem oils purchased from stores in Abuja which includes; two Nigerian brands coded as Nig NOI and Nig NOII, and a foreign brand coded as FN NO. The unbranded sample is locally processed neem oil purchased from a local market. While the neem oils extracted in our laboratory using mechanical press extraction method were branded as NIPRDNEEM Oil. To obtain NIPRDNEEM oils, viable neem seeds were sourced from Mashi local government area Kastina state Northeastern region of Nigeria. The seeds were identified at the herbarium unit of the National Institute of Pharmaceutical Research and Development, Abuja. The seeds were manually cleaned to remove adhering sand and other foreign organic matters. The cleaned neem seeds were dried at $40^{\circ} \mathrm{C}$ for $24 \mathrm{~h}$. Furthermore, the neem seeds were dehulled, a pressing machine was used to extract oil from the dried neem seed by physical crushing.

\subsection{Preparation of Fatty Acid Methyl Esters (FAMEs)}

The fatty acid methyl esters (FAMEs) of each neem oil sample were prepared as described in the United States Pharmacopoeia, 2020. Briefly, $100 \mathrm{mg}$ of the oil was placed in a $50 \mathrm{~mL}$ conical flask fitted with a suitable refluxed condenser and a magnetic stir bar. $4 \mathrm{~mL}$ of $0.5 \mathrm{~N}$ methanolic sodium hydroxide solution (prepared by dissolving $2 \mathrm{~g}$ of sodium hydroxide in $100 \mathrm{~mL}$ of methanol) was added, and reflux for 10 minutes, after which $5 \mathrm{~mL}$ of a solution prepared by dissolving $14 \mathrm{~g}$ of boron trifluoride in $100 \mathrm{~mL}$ of methanol, was added and swirl to mix, and refluxed for 2 minutes. This step was followed by adding $4 \mathrm{~mL}$ of chromatographic grade $n$-heptane through the condenser and refluxed again for 1 minute, the mixture was allowed to cool, and then the condenser was removed, $15 \mathrm{~mL}$ of saturated sodium chloride solution was added, shaken, and the layers allowed to separate. The $n$-heptane layer was passed into a suitable flask through 
$0.1 \mathrm{~g}$ of anhydrous sodium sulfate which has been previously washed with chromatographic grade $n$-heptane. $1.0 \mathrm{~mL}$ of this solution of the FAMEs was transferred into a $10 \mathrm{~mL}$ volumetric flask, made up to the mark with the $n$-heptane, mixed, filtered using 0.22-micron filter and used immediately for GC-MS analysis.

\subsection{Gas Chromatography-Mass Spectrometry (GCMS) Analysis}

The FAMEs were analysed by Gas chromatography-Mass spectrometry as per the method reported by [20]. The samples were analyzed by GC-MS using Shimadzu QP-2010 GC with QP-2010 Mass Selective Detector [MSD, operated in the EI mode (electron energy $=70 \mathrm{eV}$ ), scan range of $35-700 \mathrm{amu}$, and scan rate of 0.3 scans/sec], and Shimadzu GCMS solution data system. The Gas chromatography column was Optima-5 ms fused silica capillary with 5\% phenyl-methylpolysiloxane stationary phase, with length of $30 \mathrm{~m}$, internal diameter of $0.25 \mathrm{~mm}$ and film thickness of $0.25 \mu \mathrm{m}$. The carrier gas was helium with flow rate of $1.61 \mathrm{~mL} / \mathrm{min}$. The program used for Gas chromatography oven temperature was $100^{\circ} \mathrm{C}$ $260^{\circ} \mathrm{C}$ at a rate of $8^{\circ} \mathrm{C} / \mathrm{min}$, and then held at $260^{\circ} \mathrm{C}$ for $2 \mathrm{~min}$, followed by $260^{\circ} \mathrm{C}$ - $300^{\circ} \mathrm{C}$ at a rate of $8^{\circ} \mathrm{C} / \mathrm{min}$, then again held at $300^{\circ} \mathrm{C}$ for $2 \mathrm{~min}$. The injection port temperature was $250^{\circ} \mathrm{C}$ while detector temperature was $300^{\circ} \mathrm{C} .1 .0 \mu \mathrm{L}$ of sample was injected using autosampler and in the split mode with ratio of 5:1. Individual constituents were identified by comparing their mass spectra with known compounds and NIST Mass Spectral Library (NIST 11). The percentages of each component are reported as raw percentages based on the total ion current.

\subsection{Chemometric Data Analysis}

Principal component analysis (PCA) and Hierarchical clustering analysis (HCA)

PCA and HCA was performed on the common chromatographic peaks generated from the GCMS analysis using SOLO 8.9 a standalone chemometric software developed by Eigenvector research incorporated and powered by PLS_Toolbox. The HCA was done using the Ward's method as the amalgamation rule and the squared Euclidean distance as metric was used to establish clusters.

\section{Results and Discussion}

The quality of oils generally depends on their composition, which in turn affects their properties. Moreover, neem seed oil contains mainly fatty acids as one of the active constituents [18]. The interesting feature of the neem seed oil is that it predominantly constitutes fatty acids, along with hydrocarbons and other compounds according to [21]. This study investigated the differences in the fatty acids and volatile chemical composition of NIPRDNEEM oil and four purchased neem seed oil samples. To obtain the fatty acids profile of the neem seed oils, after derivatization, the samples were injected into the GCMS machine. The result 
of the analyses is presented in Table 1. Although oftentimes the quality of neem Seed oil has been ascribed to azadiratchin content [18], the fatty acid profile of neem seed oil is also informative and could be used to monitor the quality of neem seed oil. From the result obtained in this study, NIPRDNEEM oil tends

Table 1. Percentage chemical composition of some branded neem seeds oil sold in Nigeria.

\begin{tabular}{|c|c|c|c|c|c|c|}
\hline & & & Unbranded & & Branded & \\
\hline Chemical compounds & Relative retention time & NIPRDNEEM oil & Local neem oil & NG NOI & NG NOII & FG NO \\
\hline Palmitic acid & 0.887 & 23.4 & 12.34 & 7.84 & 11.99 & 6.88 \\
\hline Henicosane & 0.939 & - & - & - & - & 5.78 \\
\hline Linoleic acid & 0.995 & 15.94 & 14.62 & 7.32 & 8.16 & 11.17 \\
\hline Oleic acid & 1.000 & 34.09 & 30.04 & 20.58 & 26.76 & 13.5 \\
\hline Somentol & 1.011 & - & 5.15 & 7.99 & 1.0 & 1.59 \\
\hline Stearic acid & 1.016 & 11.4 & 14.91 & 13.26 & 11.96 & 5.99 \\
\hline Stearic acid amide & 1.034 & - & 5.51 & 9.07 & - & - \\
\hline Farnesyl acetate & 1.055 & - & 3.06 & 4 & 3.86 & 4.71 \\
\hline gamma.-Sitosterol & 1.065 & - & - & - & 3.71 & 5.38 \\
\hline Gorgosterol & 1.106 & - & & - & - & 1.35 \\
\hline Arachidic acid & 1.151 & 0.73 & 0.93 & 0.53 & 1.27 & 1.22 \\
\hline 1-Heptatriacotanol & 1.169 & - & - & 3.01 & - & 1.17 \\
\hline Erucylamide & 1.172 & - & 3.33 & - & - & - \\
\hline $\begin{array}{c}\text { Cinnamic acid, } \\
\text { 4-hydroxy-3-methoxy-, }\{5 \text {-hydroxy }\end{array}$ & 1.189 & - & 4.35 & - & - & - \\
\hline Cedrol & 1.210 & - & - & 8.37 & - & 0.89 \\
\hline Gamma.-Tocopherol & 1.227 & - & - & 2.71 & - & - \\
\hline Neoclovene oxide & 1.232 & - & - & 2.7 & 12.3 & 2.13 \\
\hline Dihydro-.beta.-agarofuran & 1.243 & - & - & - & 1.44 & - \\
\hline 2-Dodecen-1-yl(-)succinic anhydride & 1.288 & - & - & - & 1.9 & 0.26 \\
\hline Montanyl alcohol & 1.313 & - & - & - & - & 0.73 \\
\hline Nonacosane & 1.342 & - & - & 3.81 & 3.19 & 4.08 \\
\hline Diazoprogesterone & 1.378 & - & - & 1.98 & 2.61 & 4.66 \\
\hline Lycopene & 1.382 & - & - & - & - & 6.94 \\
\hline Cholest-7-en-3-ol, 14-methyl-, $(3 \beta)$ & 1.392 & - & 0.46 & 0.89 & 2.35 & 0.39 \\
\hline$\beta$-Stigmasterol & 1.398 & - & - & 1.56 & 2.1 & - \\
\hline Retinol & 1.401 & - & - & - & - & 11.98 \\
\hline Cholesterol, myristate & 1.411 & - & - & 1.16 & - & 1.11 \\
\hline $\begin{array}{l}\text { 1-Monolinoleoylglycerol } \\
\text { trimethylsilyl ether }\end{array}$ & 1.430 & 0.95 & - & 3.22 & 1.51 & 3.44 \\
\hline Farnesyl alcohol & 1.490 & 13.20 & - & - & - & - \\
\hline
\end{tabular}

NG NOI and NG NOII are Nigeria brands of neem seed oil while FG NO is a foreign brand of neem oil. 
to be richer in fatty acids compared to those samples which were purchased, since the content of oleic acid, palmitic acid, and linoleic acid in NIPRDNEEM oil were higher when compared with others. Across all samples five (5) fatty acids namely; Oleic acid, Palmitic acid, Linoleic acid, Stearic acid, Arachidic acid were the major fatty acid present in all samples. While these fatty acids could serve as marker compounds for quality control purposes in neem seed oil, Farnesyl acetate, Cholest-7-en-3-ol, 14-methyl-, $(3 \beta)$, and Somentol were detected in all the purchases neem oil and absent in NIPRDNEEM oil. Neoclovene oxide, Nonacosane, and Diazoprogesterone were detected in the branded samples and absent in NIPRDNEEM oil and the unbranded local neem oil. 1-Monolinoleoylglycerol trimethylsilyl ether was absent in the local oil and detected in NIPRDNEEM oil and the branded oils. Although Farnesyl acetate was detected in both local and branded oil and absent in NIPRDNEEM oil, it is interesting to note that, Farnesyl alcohol was detected as a major peak in NIPRDNEEM oil.

Among the purchased neem oils, the branded neem seed oil is composed of palmitic acid (6.88\% - 11.99\%), linoleic acid (7.32\% - 11.17\%), oleic acid (13.50\% - 26.76\%), stearic acid (4.29-13.08\%), arachidic acid (0.53\% - 1.27\%). other compounds are somentol (1.0\% - 7.99\%, farnesyl acetate $(3.86 \%-4.71 \%)$, neoclovene oxide $(2.13 \%-12.3 \%)$, nonacosane $(3.19 \%-4.08 \%)$, diazoprogesterone (1.98\% - 4.66\%), cholest-7-en-3-ol, 14-methyl-, (3. beta.)- $(0.39 \%-2.35 \%)$ and 1-Monolinoleoylglycerol trimethylsilyl ether $(1.51 \%-3.44 \%)$ as shown in Table 1. The Percentage composition of fatty acid of the local unbranded neem seed oil revealed oleic acid (30.04\%), stearic acid (14.91\%), linoleic acid (14.62\%), palmitic acid (12.34\%), arachidic acid (0.93\%), stearic acid amide (5.51\%), somentol $(5.15 \%)$, and farnesyl acetate (3.06\%). While the fatty acid in NIPRDNEEM oil was oleic acid (34.09\%), stearic acid (11.4\%), linoleic acid (15.94\%), palmitic acid (23.4\%), arachidic acid $(0.73 \%)$, the other compounds are; 1-Monolinoleoylglycerol trimethylsilyl ether (0.95\%) and farnesyl alcohol (13.20\%) as shown in Table 1.

Characterization of the fatty acid profile of neem seed oil is vital for industrial and economic purposes, where organic chemistry plays a fundamental role. It has been reported that neem seed contains $40 \%$ - $45 \%$ of oil and the remaining is the cellular matrix of the seeds. The oil is brownish yellow, non-drying oil with an acrid taste and unpleasant odor [22]. Among the botanical insecticides currently marketed, the neem seed oil is one of the least toxic to humans and shows very low toxicity to beneficial organisms, so it is, therefore, very promising for the control of many pests and its numerous uses aside pest control. The neem seed oil is also used as an ointment in cosmetics and skincare products. The versatility of the neem seed oil is ascribed to the different kinds of chemical compounds present in it. Neem seed oil is a major source of fatty acid and is mainly composed of oleic acid (50\%-60\%), palmitic acid (13\% - 15\%), stearic acid (14\% - 19\%), linoleic acid (8\% - 16\%), and arachidic acid (1\% - 3\%). Oleic acid, linoleic acid, and $\alpha$-linoleic acid are the principal $\omega-9, \omega-6$, and $\omega-3$ fatty acids, respectively [23] [24]. Similarly, the neem seed oils investigated in this study 
contains oleic acid, palmitic acid, stearic acid, linoleic acid, and arachidic acid. However, the contents vary from what is reported in the literature, the Oleic content ranged from $10.47 \%$ - 34.09\%, linoleic $4.93 \%$ - 15.94\%, stearic $4.29 \%$ $14.91 \%$, palmitic $4.77 \%-23.40 \%$, arachidic $0.53 \%-8.40 \%$. By analyzing neem seed oil with GC-FID, Djenontin et al. [21], reported the prominent fatty acids as oleic (43.5\%), linoleic (18.7\%), palmitic (17.8\%), and stearic (17.4\%) acids. The lower amount of oleic acid observed in this study could be ascribed to different factors such as seasonal variation, time of harvesting, growing conditions, and other biotic and abiotic factors.

The complex nature of neem seed oil was reported by [25]. Aside from fatty acids, It is also composed of sterols and tocopherol [22] [26]. The major sterols reported in neem seed oil are sitosterol, stigmasterol, campesterol, and fucosterol [18] [27]. Stigmasterol, Stigmasterol acetate, and Sitosterol, are the sterols identified in this study. In another study by [22], HPLC was used to analyze the presence of sterols; and $\beta$-sitosterol (77.7\%) was identified as the major sterol. This is in agreement with the work of [27].

\subsection{Chemometric Analysis}

\subsubsection{Principal Component Analysis (PCA)}

The data generated from the GCMS analysis of the neem oils were subjected to unsupervised pattern recognition analysis via PCA; the data has a computational matrix of dimension $(31 \times 5)$. Both the score plot in Figure 1 and the hotelling T2 plot in Figure 2, grouped the neem oils into three major groups. One of the groups comprised of NIPRDNEEM oil and the local neem oil. The second group includes the NG NOI and NG NOII which are both Nigerian brands of neem oil. The third group comprises FG NO a foreign brand of neem oil. The PCA grouping shows that NIPRDNEEM oil and the local neem seed oil have little chemical variation between them. It is noteworthy that NIPRDNEEM oil was extracted by cold press method, from neem seed sourced from northwest geopolitical zone of Nigeria. NIPRDNEEM OIL does not contain any additives; it is pure unadulterated neem oil. Furthermore, the GCMS analysis presented in Table 1 shows that both NIPRDNEEM OIL and the local neem oil have few peaks in them and the percentage composition of the fatty acids (palmitic acid, linoleic acid, oleic acid, stearic acid, and arachidic acid) in them were higher when compared with the other brands of neem oils analyzed.

\subsubsection{Hierarchical Cluster Analysis (HCA)}

The similarity and closeness of the neem oils are illustrated by cluster analysis [28]. Hierarchical Cluster Analysis was performed on the datasets generated from the GCMS analysis. The output is illustrated in form of dendrogram which is presented in Figure 3. The similarities or closeness of the neem oils are measured by the variances of the weighted distance between the centers of clusters. Ward's method according to [29], was adopted in the analysis. HCA revealed that the neem oils are clustered into three subgroups, one of the groups contains 


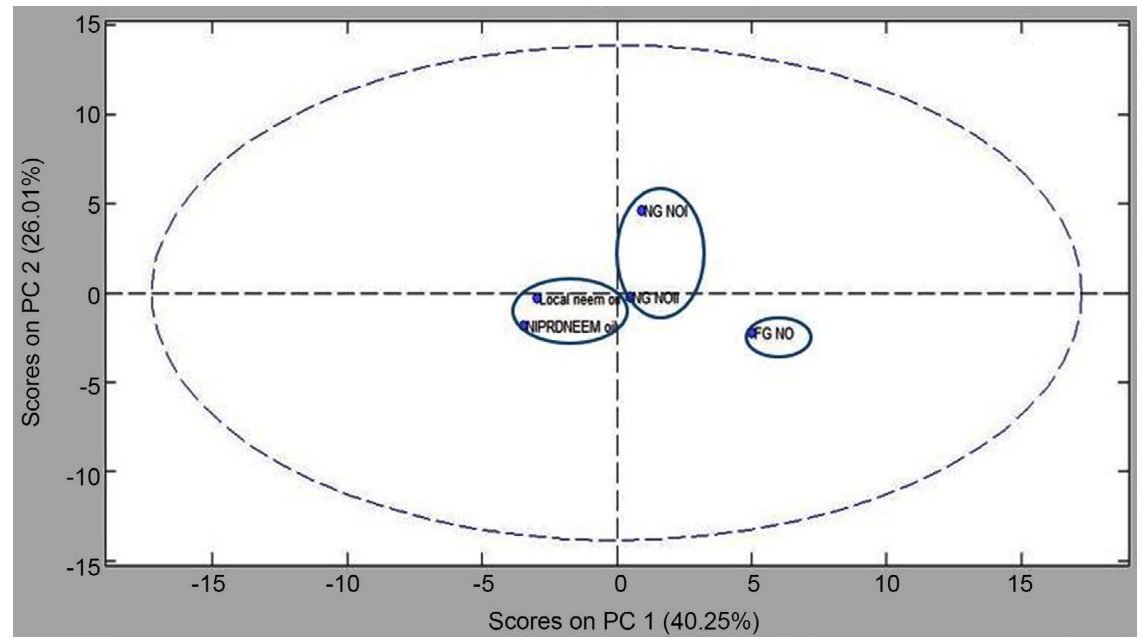

Figure 1. Score plot of neem oils.

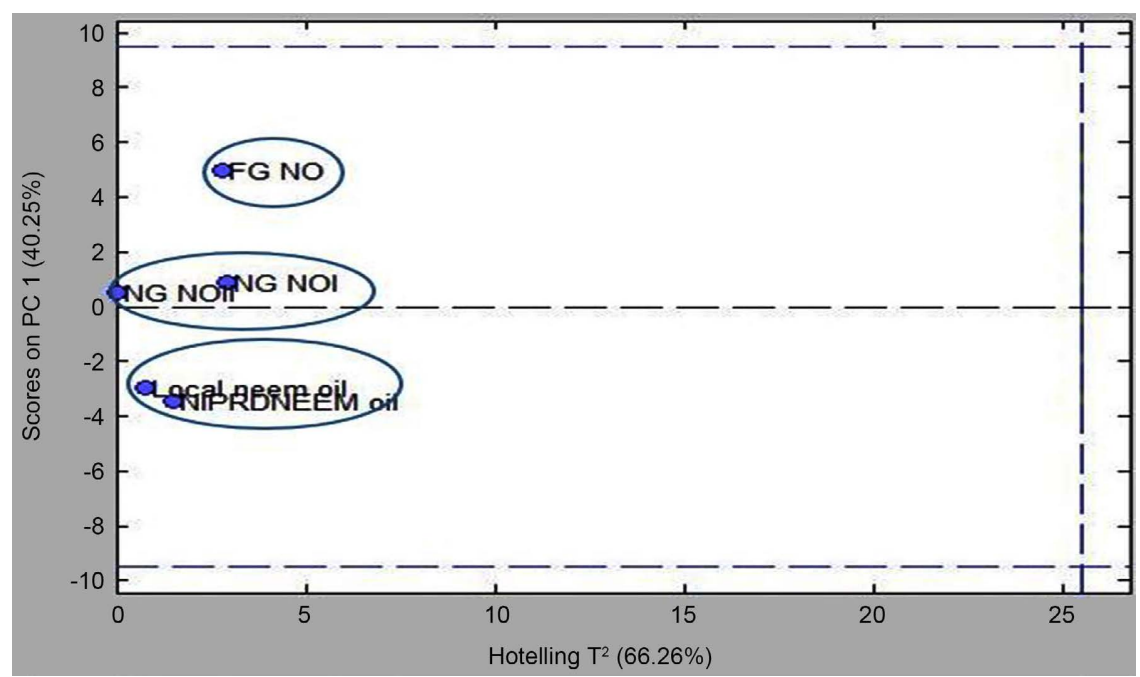

Figure 2. Hotelling $\mathrm{T}^{2}$ plot of neem oils.

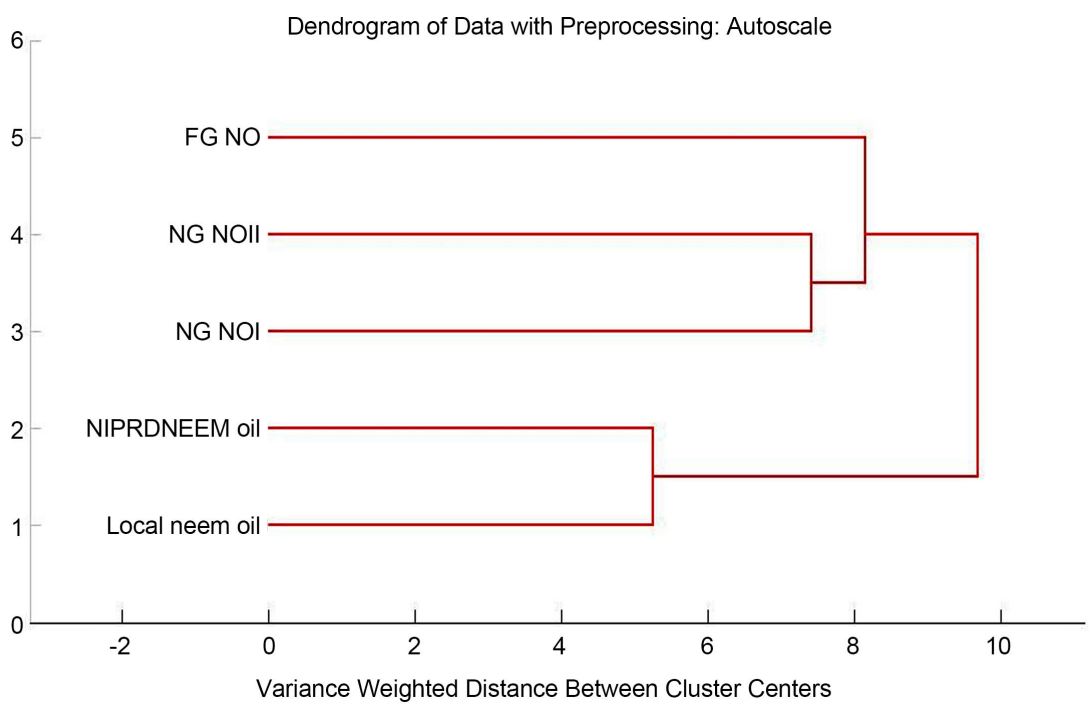

Figure 3. HCA Dendrogram of neem oils. 
NIPRDNEEM OIL and the local neem seed oil. The second group is the two Nigerian brands NG NOI and NG NOII and the third group is FG NO (Figure 3) the foreign brand. The pair NG NOI and NG NOII and FG NO are in a close neighborhood based on variance weighted distance from Figure 3. Cluster analysis of the samples reveals information about closely related neem oil which can be interpreted as resemblance in chemical composition and the extraction method used.

\section{Conclusion}

This study has shown that the fatty acids of NIPRDNEEM oil are similar to those of other brands and that the fatty acids content in NIPRDNEEM oil is higher than those in the other oils analyzed in this study. The following fatty acid; oleic acid, palmitic acid, stearic acid, linoleic acid, and arachidic acid are detected in all the neem oils samples. This has shown that these fatty acids could be used as marker compounds for quality control of neem seed oils to ensure consistency in neem batches being produced. Neem seed oil is widely used as medicinal, cosmetic, and agricultural products. Studies have shown that the method used to extract the oil can affect the distribution of components and manifest quantitative changes in the oil composition. However, chemical fingerprinting or key active components help to determine the purity as well as the potency of the oil. Due to the high market price of neem seed oil, they could be adulterated, diluted, or substituted with poor-quality oils, cheap terpenes, and low-density petroleum fractions. Therefore, analysis of the oil to ensure that the major chemicals or markers like oleic acid, palmitic acid, stearic acid, linoleic acid, and arachidic acid fall within an acceptable range is key for authentication of acceptable industrial standards. The chemometric analysis shows that NIPRDNEEM and the local neem oil are grouped suggesting a high degree of resemblance of both samples.

\section{Acknowledgements}

The authors acknowledge the Federal Ministry of Health, management of NIPRD for funding the neem project and Mallam Ibrahim Muazzam of the department of Medicinal plant research and traditional medicines, NIPRD, for his contribution to this study.

\section{Conflicts of Interest}

The authors declare no conflicts of interest regarding the publication of this paper.

\section{References}

[1] Ghimeray, A.K., Jin, C.W., Ghimire, B.K. and Cho, D.H. (2009) Antioxidant Activity and Quantitative Estimation of Azadirachtin and Nimbin in Azadirachta indica A. Juss Grown in Foothills of Nepal. African Journal of Biotechnology, 8, 3084-3091.

[2] Olabinri, B.M., Adebisi, J.A., Odesomi, O.F., Olabinri, P.F. and Adeleke, G.E. (2009) 
Experimental Classification of the Antioxidant Capacity of the Leaf, Stem and Root Barks of Mengifera indica and A. indica. African Journal of Biotechnology, 8, 29682972.

[3] Aromdee, C. and Sriubolmas, N. (2006) Essential Oil of the Flowers of Azardirachta indica A. Juss (Meliaceae). Journal of Science and Technology, 28, 115-119.

[4] Rashid, A., Ahmad, I., Iram, S., Mirza, J.I. and Rauf, C.A. (2004) Efficiency of Different Neem (Azardirachta indica A. Juss) Products against Various Life Stages of Phytophthora infestans (Mont.) de Bary. Pakistan Journal of Botany, 36, 881-886.

[5] Biswas, K., Chattopadhyay, I., Banerjee, R.K. and Bandyopadhyay, U. (2002) Biological Activities and Medicinal Properties of Neem (Azadirachta indica). Current Science, 82, 1336-1345.

[6] Lucantoni, L., Giusti, F., Cristofaro, M., Pasqualini, L., Esposito, F. and Lupetti, P. (2006) Effects of a Neem Extract on Blood Feeding, Oviposition and Oocyte Ultrastructurein Anophelesstephensi Liston (Diptera: Culicidae). Tissue Cell, 38, 361-371. https://doi.org/10.1016/j.tice.2006.08.005

[7] Chandramohan, B., Murugan, K., Madhiyazhagan, P., Kovendan, K., Kumar, P.M., Panneerselvam, C., et al. (2016) Neem By-Products in the Fight against Mosquito-Borne Diseases: Biotoxicity of Neem Cake Fractions towards the Rural Malaria Vector Anopheles culicifacies (Diptera: Culicidae). Asian Pacific Journal of Tropical Biomedicine, 6, 472-476. https://doi.org/10.1016/j.apjtb.2015.11.013

[8] Scudeler, E.L., Garcia, A.S.G., Padovani, C.R. and Santos, D.C. (2013) Action of Neem Oil (Azadirachta indica A. Juss) on Cocoon Spinning in Ceraeochrysa claveri (Neuroptera: Chrysopidae). Ecotoxicology and Environmental Safety, 97, 176-182. https://doi.org/10.1016/j.ecoenv.2013.08.008

[9] Scudeler, E.L. and dos Santos, D.C. (2013) Effects of Neem Oil (Azadirachta indica A. Juss) on Midgut Cells of Predatory Larvae Ceraeochry saclaveri (Navás, 1911) (Neuroptera: Chrysopidae). Micron, 44, 125-132. https://doi.org/10.1016/j.micron.2012.05.009

[10] Senthil Nathan, S., Kalaivani, K., Sehoon, K. and Murugan, K. (2006) The Toxicity and Behavioural Effects of Neem Limonoids on Cnaphalocrocis medinalis (Guenée), the Rice Leaf Folder. Chemosphere, 62, 1381-1387. https://doi.org/10.1016/j.chemosphere.2005.07.051

[11] Weathersbee, A.A. and McKenzie, C.L. (2005) Effect of Aneembio Pesticide on Repellency, Mortality, Oviposition, and Development of Diaphorina citri (Homoptera: Psyllidae). Florida Entomologist, 88, 401-407. https://doi.org/10.1653/0015-4040(2005)88[401:EOANBO]2.0.CO;2

[12] Ahmad, S., Ansari, M.S. and Muslim, M. (2015) Toxic Effects of Neem Based Insecticides on the Fitness of Helicoverpa armigera (Hubner). Crop Protection, 68, 72-78. https://doi.org/10.1016/j.cropro.2014.11.003

[13] Seljåsen, R. and Meadow, R. (2006) Effects of Neem on Ovi Position and Egg and Larval Development of Mamestra brassicae L: Dose Response, Residual Activity, Repellent Effect and Systemic Activity in Cabbage Plants. Crop Protection, 25, 338-345. https://doi.org/10.1016/j.cropro.2005.05.007

[14] Senthil-Nathan, S., Choi, M.-Y., Seo, H.-Y., Paik, C.-H. and Kalaivani, K. (2009) Toxicity and Behavioural Effect of 3b, 24,25-Trihydroxycycloartane and Bed Domeilactone on the Rice Leaf Folder Cnaphalocrocis medinalis (Guenée) (Lepidoptera: Pyralidae). Ecotoxicology and Environmental Safety, 72, 1156-1162. https://doi.org/10.1016/j.ecoenv.2008.02.005

[15] Hasan, F. and Shafiq Ansari, M. (2011) Toxic Effects of Neem-Based Insecticides on 
Pieris brassicae (Linn.). Crop Protection, 30, 502-507. https://doi.org/10.1016/j.cropro.2010.11.029

[16] Tavares, W.S., Costa, M.A., Cruz, I., Silveira, R.D., Serrão, J.E. and Zanuncio, J.C. (2010) Selective Effects of Natural and Synthetic Insecticides on Mortality of Spodoptera frugiperda (Lepidoptera: Noctuidae) and Its Predator Eriopis connexa (Coleoptera: Coccinellidae). Journal of Environmental Science and Health, Part B, 45, 557-561. https://doi.org/10.1080/03601234.2010.493493

[17] Hassan, A., Salau, R.B. and Tijani, J.O. (2019) Evaluation of Nutritional Composition and Chemometric Characterization of Some Varieties of Date Fruits. Journal of Science, Technology, Mathematics and Education (JOSTMED), 15, 23-36.

[18] Khanam, Z., Al-Yousef, H.M., Singh, O. and Bhat, I.U. (2017) Neem Oil. In: Green Pesticides Handbook, Routledge, London, 377-399. https://doi.org/10.1201/9781315153131-20

[19] Liauw, M.Y., Natan, F.A., Widiyanti, P., Ikasari, D., Indraswati, N. and Soetaredjo, F.E. (2008) Extraction of Neem Oil (Azadirachta indica A. Juss) Using $n$-hexane and Ethanol: Studies of Oil Quality, Kinetic and Thermodynamic. Journal of Engineering and Applied Sciences, 3, 49-54.

[20] Narsing Rao, G., Prabhakara Rao, P.G. and Satyanarayana, A. (2014) Chemical, Fatty Acid, Volatile Oil Composition and Antioxidant Activity of Shade Dried Neem (Azadirachta Indica L.) Flower Powder. International Food Research Journal, 21, 807-813.

[21] Djenontin, T.S., Wotto, V.D., Avlessi, F., Lozano, P., Sohounhloue, D.K.C. and Pioch, D. (2012) Composition of Azadirachta indica and Carapa procera (Meliaceae) Seed Oils and Cakes Obtained after Oil Extraction. Industrial Crops and Products, 38, 39-45. https://doi.org/10.1016/j.indcrop.2012.01.005

[22] Johnson, S. and Morgan, E.D. (1997) Supercritical Fluid Extraction of Oil and Triterpenoids from Neem Seeds. Phytochemical Analysis, 8, 228-232. https://doi.org/10.1002/(SICI)1099-1565(199709/10)8:5<228::AID-PCA367>3.0.CO; $\underline{2-\mathrm{C}}$

[23] Mongkholkhajornsilp, D., Douglas, S., Douglas, P.L., Elkamel, A., Teppaitoon, W. and Pongamphai, S. (2005) Supercritical $\mathrm{CO}_{2}$ Extraction of Nimbin from Neem Seeds-A Modelling Study. Journal of Food Engineering, 71, 331-340.

https://doi.org/10.1016/j.jfoodeng.2004.08.007

[24] Ismadji, S., Kurniawan, A., Ju, Y.H., Soetaredjo, F.E., Ayucitra, A. and Ong, L.K. (2012) Solubility of Azadirachtin and Several Triterpenoid Compounds Extracted from Neem Seed Kernel in Supercritical $\mathrm{CO}_{2}$. Fluid Phase Equilibria, 336, 9-15. https://doi.org/10.1016/j.fluid.2012.08.026

[25] Ricci, F., Berardi, V. and Risuleo, G. (2009) Differential Cytotoxicity of MEX: A Component of Neem Oil Whose Action Is Exerted at the Cell Membrane Level. Molecules, 14, 122-132. https://doi.org/10.3390/molecules14010122

[26] Djibril, D., Mamadou, F., Gerard, V., Geuye, M.D.C., Oumar, S. and Luc, R. (2015) Physical Characteristics, Chemical Composition and Distribution of Constituents of the Neem Seeds (Azadirachta indica A. Juss) Collected in Senegal. Research Journal of Chemical Sciences, 5, 52-58.

[27] Momchilova, S., Antonova, D., Marekov, I., Kuleva, L., Nikolova-Damyanova, B. and Jham, G. (2007) Fatty Acids, Triacylglycerols, and Sterols in Neem Oil (Azadirachta Indica A. Juss) as Determined by a Combination of Chromatographic and Spectral Techniques. Journal of Liquid Chromatography and Related Technologies, 30, 11-25. https://doi.org/10.1080/10826070601034188 
[28] Salau, R.B. and Hasan, M.N. (2019) Quantitative and Chemometric Study of Patterns, Distributions and Health Status of Chromium, Cobalt, Nickel and Molybdenum in Selected Malaysian Dishes. Journal of Science, Technology, Mathematics and Education (JOSTMED), 15, 8-22.

[29] Meloun, M., Milithy, J. and Forina, M. (1992) Chemometrics for Analytical Chemistry. Ellis Horwood, New York. 